\title{
Creaming and parking in marketised employment services: An Anglo-German comparison
}

\begin{abstract}
The delivery of public services by nonprofit and for-profit providers alters the nature of services and jobs, often in unintended and undesired ways. We argue that these effects depend on the degree to which the service is 'marketised', i.e. whether it is subject to pricebased competition by the funder. Using case studies of British and German employment services, this paper scrutinises the link between marketised funding, professional autonomy, and service quality. Of particular concern in employment services is the problem of 'creaming and parking', in which providers respond to market incentives by selecting jobready clients for services and neglecting clients more distant from the labour market. We explore three questions. First, what are the mechanisms through which marketization leads to the emergence of commercial providers where creaming and parking might be expected? Second, what are the mechanisms through which marketization puts pressure on noncommercial providers that might resist pressures to cream and park? Third, what institutions might serve as a buffer for the landscape of service provision facing price-based competition?
\end{abstract}

Keywords: Marketisation of employment services; quasi-markets; contracted-out public services; vouchers; private and nonprofit sector; front-line service work. 


\section{Introduction}

Across the world 'the market' has become a general-purpose toolbox for solving policy problems, and employment services - the task of moving jobless people into, or towards, paid employment - a much-studied site where these tools are used (e.g. Hipp and Warner, 2008; Jantz et al 2016). In these complex services for vulnerable clients, the policy literature often finds providers responding to marketization by providing only a minimal service for clients deemed distant from the labor market and focusing attention on job-ready clients, a problem known as 'creaming and parking' (e.g. Bredgaard and Larsen, 2008; Rees et al, 2013b).

In the employment relations literature, these trends toward contracting and their consequences are examined as part of 'New Public Management' (NPM). Prominent issues include the erosion of professional autonomy and deterioration in the quantity and quality of staff-client interactions (e.g. Foster and Hoggett, 1999; Baines, 2004). While NPM has not eradicated the ethos of public service in restructured workplaces (Hebson et al, 2003; Rosenthal and Peccei, 2006), it has led to the devaluing of formal qualifications and exit of experienced workers (Ranald, 1999), put financial pressures on nonprofit organisations (Cunnningham and James, 2008), and spread internationally (Bach and Bordogna 2011).

Among the tools of NPM are contracting and vouchers, market mechanisms that can lead to the above-mentioned outcomes. They can also have disorganising effects on collective bargaining and worker participation institutions, contributing (as studies in Germany have shown) to wage restraint and work intensification (Doellgast, 2012; Greer et al, 2013). Policies to mitigate them include transfer of undertakings and statutory wage rules (Grimshaw and Miozzo, 2009) and social criteria in public procurement (Jaehrling, 2015). Less understood are particular market mechanisms, or the conditions under which they have these effects. 
This paper contributes to the policy and employment relations literatures, first by defining and operationalizing marketization in government-funded services. Second, it identifies two mechanisms through which it produces organizational change, including creaming and parking. Our first two research questions concern the mechanisms that lead to (1) the rise of commercial models of service provision and (2) pressure on traditional nonprofit models. Third, it explores the differences between commercial and non-commercial provision in Germany and Britain, which present contrasting theoretical images of ‘coordinated' versus 'liberal' political economies (Hall and Soskice 2001). We present data on differences between these four market segments in terms of governance, labor process, and whether there is creaming and parking. Our third research question concerns the effects of national institutions on the above two mechanisms.

We have three main findings about these organizations under marketization. First, a 'commercial model' emerges of mostly for-profit services, characterised by tight management control and institutionalized creaming and parking. Second, a 'social-services model' of mostly nonprofit providers declines, as financial pressures mount on organisations with more professional autonomy in the labour process; these organisations resist pressures to cream and park with varying degrees of success. Third, these effects are weaker in German public purchasing because of institutional supports for worker skills protected by the funder.

In what follows, we ground our research questions in the literature, present our methods and data (for each of the three questions), and discuss broader implications.

Marketisation, professional autonomy, and service quality in employment services 
In employment services, creaming and parking is a kind of 'adverse selection' where clients are selected for assistance in inverse proportion to need. Lipsky (1980) observed it in his classic street-level bureaucracy study: front-line public-sector workers in the US sorted their clients because they did not have sufficient time to meet the needs of everyone in their caseload. When confronted with quantitative targets, they sorted clients on the basis of whether they were easy to serve and freed up time to hit targets by neglecting more difficultto-serve clients (106-107).

Evaluations have found creaming and parking in US (Anderson et al 1993), German (Bernhard and Kruppe 2010), British (Rees et al 2013b), Dutch and Australian (Bredgaard and Larsen, 2008) employment services, but it is not universal. Studies on French employment services have found sorting for 'opportunity' (i.e. to identify available services) and 'employability' (i.e. to identify clients who can be placed in the available jobs) (Paugam 1993; Schulte et al 2017). Under creaming and parking, sorting for employability dominates, with client attitudes, body language and demeanour, social status, and age used by advisors as signals of employability (Rosenthal and Peccei 2006). These job-ready clients are 'creamed' so providers can claim the incentive payments, while the others are 'parked' to minimize spending. This is a service quality problem, since it entails neglect of clients targeted by public policy, and many programme evaluators view job outcomes for clients who would have achieved them without intervention as 'deadweight' to be deducted from net effects (e.g. De Koning 1993).

Quasi-markets theory, the dominant approach in the policy literature, suggests financial incentives as an explanation for adverse selection. Le Grand (2003) argues that markets for public services differ from the theoretical constructs of economists, since they are created by a government-purchasing agent and involve a mixture of private, nonprofit, and public-sector organisations. Le Grand argues that public purchasing practices set incentives, 
and these can be used to encourage greater responsiveness of front-line workers to client needs (7-11).

It is unclear, however, what kind of incentive structure would prevent creaming and parking in employment services. While Le Grand (2003) aims to 'make the client king', the social policy behind employment services is work-first and emphasises client compulsion over free choice (Greer 2015). Adverse selection is likely when the government funder pays for job outcomes, since it creates a material incentive to place people in jobs without payment for harder-to-measure outcomes (Carter and Whitworth 2015). The main architect of the current British employment services market acknowledged the problem in calling for the payment by results system to be informed by an 'analysis of the contractual incentive structure to minimise "creaming" and "parking"” (Freud 2007). Quasi-markets theory has yet to find the solution.

One alternative is to view marketization as something bigger than the transaction, a logic of governance that includes both funding and provision. Whether they see marketization as a response to past bad performance of ALMPs (Sol and Westerveld 2005) or point out that marketization often fails to deliver on its promises (Bredgaard and Larsen 2008), much of the policy literature on employment services follows Considine and Lewis (2003) in defining marketization in terms of the overall principles of public management and the work-first welfare state. Jantz et al (2016) define 'market accountability' as 'the organization of exchange via competition and contracts' where the criteria of success are 'price, quality, and return on investment' and contrasted with democratic, administrative, and network accountability. They argue that these different forms of accountability are often combined: while the British funder uses quantitative outcome measurement while only lightly regulating the activities of providers, its German equivalent uses market accountability while tightly controlling their activities. 
Policy literature suggests that non-commercial providers would resist creaming and parking. Parking hard-to-serve clients may violate the ethos of front-line workers in noncommercial providers, as in Divay's (2008) study of French providers, where staff promote 'voluntary participation of the unemployed, needs analysis, introspection . . . to help the unemployed to be or become autonomous' (680). Under 'network accountability', where evaluation is dependent in part on provider reputation among local peer groups rather than quantitative criteria (Jantz et al 2015), this resistance would be reinforced. The task itself could frustrate management control through its sheer complexity (Brodkin 2008).

But this literature also suggests a shift toward more commercial provision, in line with the general aim of NPM to make government behave more like the private sector. Providers may face financial pressures to act more like their newer commercial competitors, disrupting local networks that underpin the complex and customised services that they provide (Hipp and Warner 2008). In Australia, the market share of non-profits has declined considerably under competitive contracting with payment by results (cite). Furthermore, as this literature documents, there are commercial providers have emerged in Britain that impose tight performance management on staff and that have engaged heavily in creaming and parking, in line with expectations from governance theory (Rees et al 2014b).

The policy literature provides many insights to the causes of creaming and parking in marketized employment services: the problem, the role of the transaction, and differences between the governance of services. But the specific features of markets that produce these outcomes are unclear. Our first question is: what are the mechanisms through which marketization leads to the emergence of commercial providers where creaming and parking might be expected? We address this question by examining commercial, mostly for-profit, providers in the two countries. 
Key to our approach is a clearer definition of marketization, which is supplied by Doellgast and Greer (2017) and based on the comparative employment relations literature. Marketization is the introduction or increase in price-based competition in transactions. It has four dimensions Funders can increase frequency by ending ongoing guaranteed funding arrangements such as annual grants and replacing it with time-limited contracts. They can strengthen the price mechanism by ending cost-recovery arrangements, allowing prices to float according to supply and demand, and allocating contracts primarily on the basis of price. Funders can increase the standardisation of the service by specifying it in a way that is general and makes it possible for many providers to bid. Finally they can open markets to new players by inviting for-profit firms into provision once carried out primarily by nonprofits or the public sector. Below we use these four dimensions to compare the transactions.

In employment relations and sociology of work, market pressures are usually defined diversely and at a lower level of abstraction. Marchington et al (2005) emphasise the introduction of new organisational boundaries in a diverse sample of workplaces; Cunningham et al (2013) highlight competition, prescriptive contracts, performance management, and reduced spending in the Scottish voluntary sector. In both of these studies, the market affects work by reducing the discretion of the employer and passing power to the funder or client (Marchington et al 2005; Cunningham 2008).

The empirical focus in this literature is typically on change in the public or non-profit sectors. As Baines (2004) argues, work-first welfare reforms are conducive to the erosion of professional autonomy because they create 'one-size-fits-all' social services aimed at servicing the private sector and because they tend to use management by numbers, deskilling, and work intensification on the front line. Detailed control of white collar work using IT and lean management tools are widespread in the British civil service (Carter et al 2011) and US 
municipal social services (Esbenshade et al 2016), which highlights the increasing speed of service. This literature also helps to explain parking by showing the reduced amount of time available for staff-client interaction (Foster and Hoggett 1998) and the exit of the staff from the sector who have the skills to address complex needs (Ranald 1999).

This literature helps to understand workplace dynamics in non-profit and publicsector and points to some of the dimensions of marketization. Our second question is: what are the mechanisms through which marketization puts pressure on non-commercial providers that might resist pressures to cream and park? We will examine this by examining non-profit and public-sector service providers in the two countries.

Market change does not automatically translate into workplace change, however; the comparative literature typically explains workplace outcomes with factors external to the transaction, such as collective bargaining, its statutory underpinning, and its enforcement (Grimshaw and Miozzo 2008; Hermann and Flecker 2011), as well as strong training institutions and worker-participation institutions in the workplace (Doellgast 2012). Publicsector contracting can be used to shore up such institutions, as Jaehrling (2015) argues, through rules that require compliance with labor standards, as is currently taking place in Germany. These factors may enable strong professional autonomy in the workplace.

But it is questionable what happens to these institutional effects when they come into contact with marketisation (Greer and Doellgast 2017). As studies on worker posting show, market change can produce uneven 'rule enactment' in industrial relations, producing wide within-country variation and gaps in workplace regulation (Wagner 2015). Greer et al (2013) found that the introduction of market mechanisms led to a wave of privatisation of German hospitals, which led in some cases to conflict and the derecognition of collective agreements and in others to intensified labour-management cooperation. In German employment 
services, collective bargaining and works councils persisted in relatively protected market segments but were absent from highly disorganised institutions in more volatile segments (Greer et al 2017). This within-country diversity is one reason why studies detect no 'varieties of NPM' corresponding to the typologies of welfare regimes or comparative capitalism (Bach and Bordogna, 2011).

Our third question is, what national institutions might serve as a buffer for the landscape of service provision facing price-based competition? We explore this through a structured comparison of the four cases.

Table 1 summarises the dynamics of selection, the different market conditions, and possible explanations and figure 1 shows how they are related in our explanation. Grey arrows represent the first mechanism (the rise of commercial model), black arrows represent the second mechanism (the strain on traditional services), and the white arrow represents conditions (national institutions).

INSERT TABLE 1 ABOUT HERE; INSERT FIGURE 1 ABOUT HERE

\section{Research methods}

In order to understand the effects of marketisation on workplaces, we examined a complex process spanning multiple organisational boundaries over a relatively long time period. Employment services were an appropriate context for this kind of study because they include a shared set of tasks but varying market structures, both between and within countries. 
Through eight years of field research we extended our framework beyond initial hypotheses and explored change over time. In keeping with case study methods (e.g. Yin 1990), we triangulated each case through different interviewees (funding bodies, management, and front-line staff) and kinds of data (interviews, publicly available reports and statistics). In keeping with qualitative comparisons (Ragin 2008), we selected cases to vary on theoretically relevant conditions (ownership of provider, market arrangements, other national institutions) and outcomes (creaming and parking). We developed mid-range theory, specifying causal mechanisms repeated under specific conditions, rather than general laws that apply in all social reality (e.g. Hedstrom and Swedberg 1998).

While past studies examined creaming and parking in particular countries (e.g. Rees et al $2013 \mathrm{~b}$ on Britain), the issue has not been studied comparatively. We chose Britain and Germany to gain variation in the sample, especially on the outcome of creaming and parking. We expected strong between-country variation due to stronger institutions of skill formation and worker participation in German workplaces (Doellgast 2012) and the decline of administrative or democratic accountability in British employment services (Jantz et al 2015) and within-country variation in Germany due to the disorganizing effects of marketisation on these institutions (Greer et al 2013). We compare the cases along conditions and outcomes to rule out or qualify possible explanations.

Our case studies are informed by 77 interviews conducted in Britain and Germany in 2006-11, mostly managers within the funders and the providers, but also trade unionists, umbrella bodies, and other policymakers, mostly with one respondent. These identified the market segments in the two countries and the effects of competition on workplaces and services. Within each country, we found different funding arrangements creating different kinds of competition, with different provider landscapes. 
In 2011-14 we conducted a second wave of 71 interviews in Britain and Germany, mostly with front-line workers and line managers, including 4 repeat interviews. We spent a day each in 6 establishments talking to 3-5 front-line workers ( 1 at a time) and their line managers; we also interviewed trade unionists, umbrella bodies, purchasing professionals, policymakers, and (in Britain) senior managers at large for-profit providers. We used sampling to deal with two factors that could affect the outcome: task (only job placement services for clients deemed distant from the labour market) and local contracting markets (only urban areas with large employment services sectors). Wave 2 interviews explored funding, the labour process, and the approach to job placement (i.e. creaming and parking). Table 2 describes our sample.

\section{INSERT TABLE 2 ABOUT HERE}

We recorded nearly all interviews, typed up notes or word-for-word transcripts, and coded them with MaxQDA. In wave 1 we developed our key concepts, line of questioning, and research design; in wave 2 we had a more structured interview template and sample. Our concepts emerged through iterations of interviewing, coding, and discussing the data and codes (Eisenhardt 1989). We carried out a final 'deductive' top-down coding of all notes and transcripts using MaxQDA lexical search and coding functions to empirically assess the cases in terms of the categories in our analytical framework.

In Great Britain our sample of providers changed, reflecting the market and organisational landscape. Wave 1 focused on non-commercial organisations - nonprofits and municipal departments - some small and some large, all with roots prior to marketization and all experiencing severe resource scarcity due to funding cuts. In wave 2 we examined the rise 
of large commercial organisations in response to the Work Programme, which centralized the market after 2010 by combining most employment services schemes across Great Britain (Wiggan 2015) and accounted for around half of the volume of employment services contracting. The Work Programme became doubly important for providers with the decline of municipal funding and the abolition of two large regional funders. In wave 2 we interviewed senior managers at several large firms and then carried out site visits at 5 Work Programme providers (1 nonprofit, 1 municipality, and 2 large commercial organisations), plus 1 nonprofit not in the Work Programme.

In Germany our provider sample reflected the more varied market structure. The nonprofits we visited in both waves originated in the religious charity work and labour movement of the $19^{\text {th }}$ and $20^{\text {th }}$ centuries; others originated in the 'new social movements' of neighbourhood-based activists in the 1970s and 1980s (Bode 2006). These providers had formed local networks, usually funded by government grants, which had been disrupted by the introduction vouchers for training and placement and public purchasing for others in 2002-5. We visited 4 commercial for-profit providers operating under vouchers and purchasing, including two multinationals. After numerous management interviews in waves 1 and 2 , we selected 2 providers for detailed attention: a for-profit provider operating under placement vouchers and a nonprofit operating under public purchasing.

In the next sections we present the British and German material, organised by research question. Following the framework laid out in table 1, the first two sections describe cases in terms of transactions, governance, the labour process and client selection; and the third deals with institutional regulation that could blunt these effects. 


\section{Question 1: The rise of commercial service models}

What are the mechanisms through which marketization leads to the emergence of commercial providers where creaming and parking might be expected? While collecting data we witnessed the rise of commercial provision under the British Work Programme (which began in 2010) and observed it in action with the German placement vouchers (introduced in 2002). Both used the price mechanism to put downward pressure on providers' costs and used payment by results to focus providers' attention on job placement outcomes. We observed management practices that enforced a quantitative results orientation and a work-first service using tight control techniques over front-line workers. Creaming and parking were evident: sorting only for employability, with job-ready clients served and needier clients neglected. In both market segments, for-profit firms dominated, although we also visited a nonprofit in Britain that had adopted a commercial approach.

The British Work Programme. The Work Programme is for some observers the paradigmatic case of marketised employment services (Jantz et al 2016), and this is reflected in the way the transaction works. Prices, for example, were set competitively in the bidding process at the beginning of the scheme. The provider that won the most contracts - Deloitte Ingeus - was the one that had the highest price scores, i.e. which offered the deepest discounts (Greer et al 2017 , appendix b). While the government predicted an annual volume of work at $£ 500 \mathrm{~m}$, in reality funding was roughly half that due to discounts and a lower number of placements than expected (NAO 2014). Bidding was in principle very open, and many of the providers had no experience providing employment services. Indeed most of the incumbents would become subcontractors of these much larger providers (called 'primes'). Figure 2 summarises the structure of the Work Programme. 


\section{INSERT FIGURE 2 ABOUT HERE}

The centralisation of contracting was accompanied by the privatisation of the governance services. The government refrained from detailed specification of the services in an attempt to harness the potential of the private sector to innovate, giving contractors discretion to design services. The government attempted to avoid creaming and parking through 'differential pricing', with maximum payments of $£ 3700$ to $£ 13,700$ for jobs sustained over two years, differentiated by client group (higher for claimants of the disability benefit Employment and Support Allowance [ESA] and lower for claimants of mainstream Jobseekers Allowance [JSA]), and through minimum service levels written by each provider and published online. As a civil servant told us about the previous regime, 'contract out, but then tell the contractor what to do and then pay them for doing the activities rather than the outcome. It's an odd way of using the private sector, really' (manager 1, funder a, wave 2).

Key Work Programme providers included the US-Australian consortium Deloitte Ingeus, UK-based welfare-to-work specialists A4e, Avanta, and Working Links, governmentcontracting generalists such as the US-based Maximus and the global firms SERCO and G4S, and commercial not-for-profit organisations such as CDG and NCG. The eight largest primes, with a combined market share of $69 \%$, were all for-profit firms operating on a multinational scale. Most primes outsourced $40-50 \%$ of the work to a supply chain of smaller organisations, while others outsourced $100 \%$ of the work (NAO 2014).

While the funder did not standardise services, the primes did. As per the tendering documents, they developed sophisticated IT systems to manage staff, contractors, and clients. 
Management interviewees at primes reported investment in proprietary software running in the millions during the rollout of the Work Programme (e.g. for-profit g). Competing organisations worked in partnership to develop these systems, and there were considerable similarities between our in-depth case-study organisations, nonprofit $j$ and for-profit $d$. Each prime rolled out its 'delivery model' across areas as large as Scotland, Wales, or half of London, as per the contract specification. Some managers depicted this standardisation as the outcome of a long learning process: 'A lot of our way why we've been successful is we have tested over the last ten years in reality. We know what works and it fits' (for-profit d). Others viewed it as a barrier to the ongoing innovation needed to be effective (e.g. for-profit e, forprofit h).

The labour process of front-line workers we interviewed at the commercial providers was tightly constrained by management. IT systems were used to standardise and automate processes and to provide detailed reports to management and staff. For-profit h used call centres for making appointments and gathering information needed to claim payments for sustained jobs. Moreover firms had discretion to cut back services, subject to 'minimum service levels', which were vague, minimalist, and varied by contractor (for the standards see DWP 2013; for the critique see NAO 2014).

When a client first attended a meeting (which was compulsory and under threat of benefit sanction), he or she would initially be assessed using an IT tool. On this basis, the client would be assigned to one of three groups, usually red (distant from the labour market), green (close to the labour market), or amber (somewhere in between). The services provided were focused on finding a job and combined group interviews with employers, basic skills training, coaching on the job search and writing a cv, as well as online courses and job search activities conducted independently. This was common to all of our site visits. Interviewees reported difficulty referring clients with complex needs to outside services or financial 
support for transportation or clothes for job interviews, because of a lack of funds (e.g. manager 3 and front-line worker 2, nonprofit c; front-line workers $1 \& 2$ public sector g).

The quickness of these processes was mentioned by a number of managers and frontline workers. One front-line worker told us, 'I wouldn't recognise some of [my clients] if I passed them in the street. In fact there was one guy starts talking to me in the lift, then I realised that he was my next appointment' (front-line worker 1, for-profit d). This was due to the fact that, as he and his colleagues told us, the average caseload was 180-200; caseloads under previous contracts had been 40-50. Here, the minimum service was one contact per fortnight - meeting, phone call, or email - which given large caseloads was common.

Every interviewee in this establishment saw monthly numerical targets of job placements as crucially important. All were aware that management could monitor their activities and performance in detail and in real time; and some used the IT system to continually compare their performance with that of their colleagues: "I always meet my targets. In fact, I go way past them. Then I'm looking at the guy next to me, who's messing about and doesn't care, and I'm thinking 'why should I bother (front-line worker 2, for-profit d)?" Workers reported that the pressure to hit targets took time away from other tasks such as working as an advocates for clients with complex needs such as lone parents (nonprofit c, front-line worker 2) and following up with the DWP to ensure that non-compliant clients were sanctioned (for-profit $\mathrm{d}$, front-line workers $2 \& 3$ ).

There were small but significant differences between the for-profits we visited and the commercialised nonprofit $\mathrm{k}$. This provider had many similarities to for-profits, including the sophisticated IT system to monitor staff and client activities. Targets were set at the group, rather than individual, level; and clients were distributed to different members of staff based on distance from the labour market, with the largest caseload for the advisor responsible for 
'red' clients and smallest caseloads for staff involved in quick job placements. This division of labour was set collectively by the group (front-line workers 1-7). Their line manager told us that this semi-autonomy was conditional on good performance: several other locations were under detailed performance management by the central office due to their failure to hit targets (manager 3).

Our interviewees in British commercial providers mentioned job insecurity. In wave 1 numerous interviewees reported insecurity caused by short contracts and declining funding, which led to redundancies and transfers of staff (trade union A, staff 1; trade union B, staff 1 \&2; and HR consultant). In wave 2 insecurity was often mentioned in connection with performance management. At for-profit $d$ front-line workers felt insecure because they had in the previous 18 months been through two turnovers of contracts, leading to a transfer exercise, applying for what was a smaller number jobs, and a stressful assessment centre experience (front-line workers 3, 4, 5). Another problem was punitive firing, which was a sensitive topic. One front-line worker discussed it openly: '[My line manager] is a good guy; you can have a laugh with him. But if you said anything you'd be out the door,' and 'you must hit targets or you're out the door' (front-line worker 3). Others discussed it in the context of other providers, as when a manager reported leaving the for-profit sector because 'I don't believe in sacking people for not hitting their targets' (nonprofit c, manager 3).

The evaluation literature on the Work Programme points to creaming and parking as a serious problem, despite differential pricing (e.g. Rees et al 2013b; Carter and Whitworth 2015). Up to March 2014 job outcome payments were claimed for $11 \%$ of ESA clients, well below the DWP's forecast 'minimum performance level' of $22 \%$; and providers estimated a decline in spending for each of these clients of 54\% since 2010 (NAO 2014). 
Our interviewees at the commercial providers did little to conceal creaming and parking from us. Processes were designed to select clients for employability quickly. At one large provider 'red' clients were assigned to an advisor whose caseload at any one time was 200 - and who told us that however he intervened many of his clients would remain unemployable (nonprofit $\mathrm{j}$, front-line worker 6) - and the others were sent to advisors working more intensively with much smaller numbers of 'green' job-ready clients (front-line workers 4 and 5). At a second large provider, advisors had caseloads of uniform size but had tightly enforced job-placement targets, forcing front-line staff to prioritise more job-ready clients; one worker, for example, said that an unfortunate consequence of the targets culture was that she would prioritise the top $20 \%$ of clients (for-profit d, front-line worker 3 ).

Many workers and managers we interviewed had a matter-of-fact attitude toward creaming and parking. A common view was expressed by one manager: 'you couldn't make ends meet without creaming and parking', since the Work Programme rewarded providers only for job placements achieved (for-profit h). Another manager summarised the commercial logic of creaming and parking as a mixture of a squeeze on resources brought about by price-based competition and the risks associated with payment by results:

So you get less people into work, and because you're getting less people into work you target, and because it's outcome based, you're going to target your resources at those people who are easiest to help. So you're going to aggressively park and cream. You cream by targeting the easy ones, you park by identifying the people you can't help and ignore them (for-profit e).

This attitude, however, was not tantamount to accepting creaming and parking as positive: in fact, these and other management and policy interviewees expressed frustration with it and discussed alternatives. The manager at for-profit e argued that a more fine-grained set of 
incentives and higher prices would create space for services for those currently being parked, and politician $\mathrm{b}$, who was deeply committed to private provision and $\mathrm{PbR}$, argued for separate schemes for mainstream JSA as opposed to ESA claimants.

German placement vouchers. Marketisation proceeded somewhat differently for German placement vouchers. Unlike the other transactions in our sample, it was a voucher-holding client, rather than a public authority, who chose the provider. This market was open to a wide range of different providers and did not even involve an accreditation process. (This was in contrast to training vouchers rolled out around the same time and the 'placement and activation vouchers' introduced in 2012, both of which did require accreditation.) Transactions were more frequent with vouchers than with contracting, since they took place whenever a voucher was redeemed. Prices were not set according to supply and demand, but they were tightly squeezed: placement voucher prices were fixed by law at $€ 2000-2500$ and frozen in nominal terms since their introduction in 2002 up to the time of writing (2017). The funder did not clearly specify the service itself, although our site visit at for-profit b suggests that low prices created little scope for a service beyond a quick job placement. Figure 3 summarises the placement voucher market.

\section{INSERT FIGURE 3 ABOUT HERE}

While these providers enjoyed considerable discretion to organise services, they were not empowered the way that Work Programme primes were. The main providers were small private firms with 10 or fewer direct employees. Unlike providers under contract with the 
Bundesagentur, their funding depended entirely on attracting voucher-holding customers. The introduction of training vouchers had led to a wave of insolvency by providers, who struggled to attract enough participants to cover their costs (for-profit a). While the placement firms were all creatures of the voucher scheme, they faced a similar level of uncertainty: for-profit a risked failing to attract enough clients or employers, which led to a focus on coordinating with front-line workers in the Bundesagentur to advertise its available job openings (manager 1, waves 1 and 2). Placement vouchers constitute a small market: numbers of placements nationwide ranged from 50,000 to 68,000 in 2004-9 (Bernhard and Kruppe 2010), and one Jobcenter manager reported annual local spending of $€ 200,000$ in a city with nearly one million residents and described the providers as self-employed people working out of their kitchens (funder a, second wave).

At for-profit $\mathrm{b}$ the labour process was tightly constrained: as with Work Programme providers there was detailed monitoring using IT systems, and the focus was on speed. One worker described sorting of clients through a 'gut feeling' acquired after 5 or 10 minutes of initial conversation, mainly small talk ('Did you get here all right? Would you like some coffee?'); on average it took three days from first meeting with a client to job placement (forprofit $b$, front-line worker 1 ).

The manager made clear to us that he viewed qualified social workers as 'the worst', because they spent excessive time discussing problems with job seekers and had insufficient focus on the job placement (manager, wave 1). Front-line interviewees reported threats of punitive firing ('arbeitsrechtliche Konsequenzen'), the frequent non-renewal of 6-month contracts used for new hires, and the use of low base pay (€1200 per month) plus $€ 80$ in bonuses per job placement to motivate staff (front-line workers 1-4). The manager was a strong believer in bonuses, since 'workers on a fixed salary do their job . . . but if you're working on a commission you step on it' (manager, wave 2)! 
At for-profit $b$, clients were either selected for an interview with an employer or sent away with a document stating that the meeting had taken place. The firm's owner emphasised in interviews that this was a tightly focused job-placement service providing employers with precisely suited applicants ('Paßgenaue Arbeitsvermittlung'), that any requirement to justify serving as opposed to rejecting applicants would impose high administrative costs. He used an example of a recruitment drive for an employer to show the central importance of selection for employability in his service:

There were 188 candidates sent by the Bundesagentur. We had 80 people who showed up for interviews. . They could not fulfil the requirements of the job, smelled of alcohol, didn't bring the application forms, were wearing jogging suits: it was a catastrophe. Out of these, 3 people got job interviews. The employer said, OK, we'll hire them ... The employer could see the rubbish $[$ Schrott $]$ sent over . . . and said, 'never again the Bundesagentur.' They would have received 188 applicants and had a huge task to process them (manager, wave 2).

There was no funding available for services not directly related to the job placement, although this manager showed interest in emerging funding opportunities for coaching and internships such as the forthcoming 'placement and activation vouchers'. Our interviewees had a matter-of-fact attitude toward quickly selecting clients for employability for particular jobs, including clients' enthusiasm but also features specific to the job such as physical strength and criminal record (manager, front-line worker b). These quick sorting procedures identified 'creamed' clients to receive a service and 'parked' clients to be sent away. ${ }^{1}$

\footnotetext{
${ }^{1}$ Some evaluation studies treat this as 'cherry picking', or in German 'raisin picking' (Bernhard and Kruppe 2010). Clients not 'creamed' are refused service by the provider but remain on the public-sector caseload;they are technically not 'parked' on the caseload of a provider.
} 
Summary. In this section we documented one mechanism through which marketisation can reshape employment services: the marketisation of funding led to the emergence of commercial providers. In Britain this was the intention of policymakers, and they were highly successful. In Germany, the aim was to overcome the Bundesagentur's monopoly in placement services, but this segment remained small. In both cases, however, creaming and parking was part of the model that emerged. As quasi-markets theory would expect (Le Grand 2003), there were strong incentives for creaming and parking under $\mathrm{PbR}$. Given the profit motive and light-touch regulation from the funder, as governance theory would expect (Jantz et al 2016), management in these providers had good reason to be responsive to these incentives. However, in the following section we will show that not all providers responded in this way.

\section{Question 2: The decline of established social-service models}

Our third question is, what institutions might serve as a buffer for the landscape of service provision facing price-based competition? We also visited established nonprofit providers that had undergone a transition to marketisation, but without adopting a commercial model. In Britain this was the transition from a diverse range of local and regional funding streams to the centralised and for-profit-dominated Work Programme. In Germany nonprofits had made a shift from grants to public purchasing in the wake of the 2003 Hartz reforms. In both cases, providers faced a shift away from a relatively closed arena of provision and co-production of services by purchaser and provider, and to opening of provision, a price squeeze and timebound contracts. In such traditional nonprofit and municipal providers, management control was looser, services more holistic, and creaming and parking something to be avoided. These funding arrangements put nonprofits under financial pressure: redundancies were common, 
and managers were concerned that employment-services contracting was financially unsustainable.

Contractors with the Bundesagentur für Arbeit. In addition to vouchers (discussed above), the Bundesagentur used two other transaction modes: grants and purchasing. The older one, grants, was retained for make-work schemes such as one-euro jobs, and covered the cost of services delegated to nonprofits under the principle of subsidiarity, usually church-affiliated social service agencies or training providers run by unions and employer associations. Purchasing and vouchers were more competitive ways of funding services aimed at increasing quality, reducing costs, and opening the market to private firms. In the words of one local Jobcenter manager, 'we design services for job seekers and not for providers' (funder a, wave 2).

Under purchasing, contracts were awarded to the provider according to some mixture of quality and price scores, which varied from scheme to scheme. Bids could be excluded for being below a quality threshold or above a price threshold, set in reference to the low bid. Price was crucial for determining who did the work, and most management interviewees at providers mentioned this as a problem without us raising it. More than the Work Programme, the work was tightly defined by the funder. The Bundesagentur's procurement arm - the Regionale Einkaufszentren (REZen) developed a catalogue of more than 40 off-the-shelf courses or schemes ('Standardprodukte') that local Jobcenters could purchase from local providers (funder b). The market was in principle open to a wide range of providers, with an online procurement platform, although the price pressure, small contracts, and continued local control reportedly made this a difficult market for international providers to win large amounts of work (for-profit providers c \& d). This competition was ongoing, with contract 
lengths between 6 and 24 months and options for extension by the Bundesagentur up to 2 years. While local Bundesagentur managers did have some options for maintaining their partnerships with local nonprofits, they encouraged open competitive tendering citing legal principles of transparency and equal treatment enshrined in European law (funder b). At the end of the research, the REZen reported concluding 13,000 contracts per year worth $€ 2$ billion (presentation, Düsseldorf 24 April 2015). Figure 4 summarises this contracting market.

\section{INSERT FIGURE 4 ABOUT HERE}

These providers had roots in a very different market from that of vouchers and were governed in a different way. Unlike the placement firms discussed above that emerged in the aftermath of the Hartz reforms, these nonprofits operating had longer histories. They had strong non-commercial identities as providers of state-funded services and actors in policy, in keeping with the German nonprofit 'model' (Bode 2003) and included some of Germany's largest private employers, the Catholic charity Caritas, the Protestant Diakonie, and the Social Democratic Arbeiterwohlfahrt.

Nonprofits $\mathrm{b}$ and $\mathrm{h}$, for example, operated hospitals, nursing homes, and other social services alongside employment services and used make-work schemes both to maintain their facilities and as a funding stream. It was affiliated with a church and top managers had theology degrees. Other nonprofit providers were newer, smaller, and secular; they were often initiated by activist social workers working with women, immigrants, and disabled people in particular neighbourhoods. While none of the organisations that we visited had management systems approaching the sophistication of for-profit providers, they did document activities in a detailed way due to reporting requirements by the funder. This was 
the largest market in our sample, with an annual value of around $€ 2$ billion at the time of research (funder b), albeit one in decline due to austerity and a decline in unemployment in Germany (Greer et al 2017, appendix c).

At nonprofit $b$, the service was holistic and embedded in the church's broader historical mission to address social needs. Joblessness was seen by the front-line workers we interviewed as one among many problems to address in the lives of their clients. Clients' needs were assessed in two half-day sessions, and this slowness was by design. Identifying and addressing complex social needs takes time, our interviewees argued (front-line worker 1 and 2). Much about this service, including assessment, referrals, and day-to-day work, was designed by the front-line workers themselves. Some were hostile to the idea of a one-sided focus on job placements, with one seeing 'human dignity' as a top priority in line with his strong Christian faith and targets a matter for management but not staff (front-line worker 2); another, with a background at a smaller activist nonprofit, argued that clients 'need a lobby' (front-line worker 3); another argued that a stronger focus on results would be welcome (front-line worker 4).

Here, the labour process exhibited semi-autonomy. Nonprofit $\mathrm{b}$ recruited front-line workers with a university degree in social work and/or adult education (typically Sozialpädagogik). Advisors were responsible for advising clients, making contacts with employers, referring them to other services, and documenting the work; there was a specialised coach as well. Job-placement numbers were discussed in team meetings 'every 23 weeks and on a weekly basis when placement numbers are low', and only in cases of very poor performance would managers speak to workers about hitting targets (managers 3 and 4, wave 2); one front-line worker claimed not to know what would happen if the collective target of job placements was not met (front-line worker 2). Staff told us that data entry was taking time away from working directly with clients, but it was not to manage individual 
performance; one worker admitted not knowing what exactly should be entered and pointed out that the Jobcenter could not access clients' files (front-line worker 1).

Insecurity was a serious problem in the providers we visited, as it is generally in the sector (Enggruber and Mergner 2007; Gläser 2011). We talked with managers at a mediumsized provider that had made one-third of its workforce redundant due to a sudden fall in funding (nonprofit a, wave 1) and a small provider had exited employment services when it lost its contract to a local nonprofit competitor (nonprofit c, wave 2). For its part, nonprofit b had recently reduced its front-line workforce from 10 to 4 and was employing any new staff were on 12-month contracts and expected the current scheme to be cancelled (managers $1 \&$ 2, wave 2; front-line worker 2). However there was no indication that this insecurity was used by management to improve performance.

At nonprofit $b$, there was no creaming or parking. While there was assessment and sorting, it was to identify needs and appropriate services as much as employability, and there was considerable scope for referrals to further services (often day care for clients' children [front-line worker c]). According to management, $60 \%$ of clients referred were unemployable, profiling was used to identify these clients and their needs, and it was not possible to send clients back to the Jobcenter (unlike with placement vouchers). While providing intensive services for needy clients was consistent with the professional ethos of staff and organisational model of the provider, this funding arrangement did not necessarily cover the provider's costs. Management planned to exit the programme if it did not hit a placement rate of $20 \%$ at the end of its contract; they also estimated that $20 \%$ of their clients were job-ready (managers $1 \& 2$ ). 
British non-commercial providers. In the second wave we visited three Work Programme contractors (a nonprofit and two municipalities) and a nonprofit not on the Work Programme. Compared to German nonprofits, workers' occupational identification was weaker and the model of provision less coherent. Creaming and parking was reported at most of these providers. However, managers lacked sophisticated systems to control the work, both workers and managers reported having a voluntary-sector ethos (in some cases receiving lower salaries than they would in the commercial sector), and they sought to reduce creaming and parking, sometimes successfully.

Networks of local policymakers and providers in England were weakened by the centrally driven marketisation process of which the Work Programme was a part (see Finn 2015). In the first wave of interviews, prior to 2010, local managers and their funders described a shift away from grants to purchasing that had reduced local flexibility to fund small schemes:

In the old days, funding was not competitive. It was first come, first serve. There would be seven-year plans, organisations would approach the council [i.e. municipality] with delivery plans. Eventually the money would run out, but there was a lot of building of capacity, showing people how to fill out the forms. There still are some grants, which are more flexible and get around some of the legal requirements around tendering. You don't prescribe; the voluntary sector has to come up with ideas (managers $1 \& 2$, funder c, wave 1).

In 2006-8 interviewees told us that the "usual inner-city money that the government kicks about that you can use" (politician a, wave 1) was on the decline, along with local government funding generally, and worried about the rise of centrally planned, marketised welfare-to-work schemes. Open competitive tendering and contracts ('service-level 
agreements') that clearly specified the work had already been introduced as best practice. Transactions, whose outcomes were increasingly uncertain, took place at regular intervals corresponding to the length of the scheme or the budget cycle, 6-12 months. While local funders had political and policy reasons to protect local voluntary sectors - as one told us, 'if it ain't broke, don't fix it' (funder e, wave 1) - purchasing specified services on the open market increased the risk that these charities would lose their funding and providers from elsewhere would 'parachute in' without local expertise. Although payment-by-results was seen by local policymakers as inappropriate for clients distant from the labour market, for whom the job outcome was unrealistic (managers, funders b, c, and d, wave 1), it was used for all three of the providers we visited in wave 2, in the case of Work Programme subcontractors mirroring the contracts between the primes and the DWP.

In wave 2 we looked more closely at the workplaces, which lacked both strong management control and professional ethos. At public sector $\mathrm{g}$ and nonprofits $\mathrm{h} \& \mathrm{i}$, they were using the electronic systems of the prime contractor, which, management interviewees told us, took a 'hard line' on performance. There were individual targets, but these could be quite low, and there were no performance-related bonuses. In municipalities the management prerogative was restricted by trade union representatives and collective bargaining. At nonprofit c work was organised collectively by the group using improvisation. Workers told us they were still learning how to recruit employers to participate in the scheme, and their division of labour emerged from front-line workers' pre-existing individual skill-sets rather than management planning or contract requirements (nonprofit c, manager 2, wave 2). At these providers the mix of professional backgrounds was similar to the for-profits, and two of the charities had recruited from for-profit welfare-to-work providers. Like the German nonprofits, job insecurity was reported at all of these providers as linked to the coming and going of contracts and not to performance management; many of our front-line interviewees 
were on temporary contracts and spoke of their jobs as something temporary, and we heard many examples of redundancies due to changes in contracts.

Although most of these providers engaged in creaming and parking, this was not in the context of intense management control, and providers sometimes mitigated it using other sources of funding. For nonprofit $\mathrm{H}$, creaming and parking was reportedly a matter of survival for a very small provider whose employees were paid for delivering the Work Programme (manager 1), and at nonprofit $\mathrm{c}$, creaming was built into the programme design set by the municipal funder with hard-to-place clients self-selecting out of the programme or sent back to the job centre (manager 1). At public sector $\mathrm{c}$, while management and worker interviewees told us that the contract made creaming and parking 'inevitable', they mitigated it somewhat by funding support services through different funding streams. At public sector $g$ we heard that the municipality had used its internal resources to avoid creaming and parking:

We have given every client the service they needed, regardless of the Work Programme pay model. We could do this because we operated the WP in conjunction with a grant-based social services programme. In effect, we have subsidised the WP with financial resources at the county's disposal. However, we are gradually pulling out of the WP by stopping new referrals (manager 1).

Summary. In this section we have illustrated a second mechanism through which marketisation can reshape employment services, which explains why its effects are not uniform: the marketisation of funding led to the decline but persistence of non-commercial providers. In Germany public purchasing practices ran roughshod over the subsidiarity principle that had previously delegated social services to civil society on a non-commercial basis. In Britain government handed control over funding these providers to the supply-chain 
management of prime contractors, with a consequence that they were forced to cream and park, depending on their particular financial situation.

As the sociology of work literature would suggest, this puts pressure on nonprofit social service providers (e.g. Baines 2004; Cunningham et al 2013). In these declining organisations, however, creaming and parking was not universal. In Germany, this difference was clearest, because was managers were constrained in a way they were not in the commercial organisations, due to the continued occupational identity of social workers. In Britain there was some variation in the degree of creaming and parking due to a combination of weak management capacity, a sense of mission shared by managers and front-line workers, and in some cases constraints relating to public-sector industrial relations arrangements, and the availability of alternative funding streams.

\section{Question 3: Marketization and other institutional effects}

What institutions might serve as a buffer for the landscape of service provision facing pricebased competition? In both groups of providers - commercial and non-commercial institutional changes developed independently of funding practices were underway with an aim of improving provision in the face of marketisation pressures. In Britain, managers were introducing a new professional body (the Institute for Employment Professionals) to compensate for the lack of a clear occupational identity and the resulting management challenges (most notably staff turnover). In Germany, managers were concerned about downward price pressures and wage dumping in bidding, but were divided over the most important institutional response, namely the sectoral minimum wage. In both countries, however, worker representation, whether unions or works councils, was absent from many workplaces. Although there were important between-country similarities - including severe 
price-based competition - the institutions of skill formation were crucial to sustaining the non-commercial approach at German providers, and that these were underpinned by the contracting practices of the Bundesagentur.

In British providers, the institutional regulation of work was relatively weak. In terms of collective bargaining and trade union presence, there was variation. At municipalities, some charities, and one for-profit provider with large numbers of former civil servants, trade union representatives were present. Trade unionists we interviewed, however, reported declining membership and workplace structures in the organisations where they were present - notably due to the turnover of contracts which led to staff turnover - and having at best aborted campaigns at the far more numerous firms where they had no structures (trade union a, staff 2-3, wave 2). Activists reported having little influence over pay and bemoaned a lack of information, even where they were present, and reported servicing as more important (lay officials $2 \& 3$ ); this was confirmed by management (for-profit d, manager 1).

For managers in the sector, however, the weak institutional regulation of work was a problem. One study carried out by the sector's umbrella body found that managers tend to see worker turnover as excessively high and perceive the lack of a clear track of career progression within the sector as one reason (Crawford and Perry 2010). The most common qualification for workers we interviewed was NVQ level 3 in Information, Advice and Guidance. This was not mandated by the funder, and staff were recruited from an extremely wide range of fields, including local government, retail sales, high-street recruitment agencies, the civil service, and the voluntary sector, including university graduates in psychologists and social work and former clients with unrelated qualifications.

A management-driven initiative to address this problem, the Institute for Employment Professionals, was nascent at the time of research, but according to management interviewees 
was having success in attracting members and designing a new curriculum for skills specific to the sector (for-profit h, umbrella d). It was difficult, however, to build support in the sector for this initiative, in part due to differences of opinion between managers as to whether formal qualifications would necessarily produce employees capable of hitting job targets. One of Crawford and Perry's (2010) management respondents put the case against occupational regulation succinctly: 'It's important to remember this is a performance-driven industry: the best performing [personal assistant] may not be the most well qualified' (20).

In Germany, we observed two market segments with different governance, workplaces and kinds of services. Small companies operating under placement vouchers had a similar amount of discretion to Work Programme providers and lacked contracts specifying the work in detail. The mixture of occupational backgrounds at for-profit b was similar to Work Programme prime providers: former clients, job centre staff, and sales occupations (manager, front-line workers 1-3). Similarly, for-profit a employed trainers with occupational backgrounds, and hourly pay, in the areas in which they taught (manager, wave 1). For-profit a reported having too few directly employed employees to be covered by the works council law, since it relied extensively on freelance teachers (management), and none of the forprofits we visited were bound to collective agreements.

Under purchasing, by contrast, providers tended to employ qualified social workers that had some form of worker representation. The contractor we examined in depth was operating under payment by results while exhibiting very strong professional autonomy in the workplace. Workplace-level worker representatives did exist in this and most other providers we visited operating under contracts with the Bundesagentur, with their roles defined in law. But their roles were restricted by the particular legal framework for trade union activities in German nonprofits (especially those covered by church law) and because staff turnover made it difficult to maintain trade union influence in the workplace outside the public sector (trade 
union b, staff 1-3). Moreover, the funder had decided not to stipulate adherence to collective agreements or wage minima in tendering processes, citing legal principles of autonomous collective bargaining and inter-regional differences in labour markets (wave 2, funder b).

The funder, however, did often stipulate professional qualifications in the specifications of work being tendered, which our REZ interviewees saw as a way to limit wage dumping: in their view providers could not recruit qualified social workers for 12 euros per hour (ibid). Although prescribing staff qualifications, experience, and numbers in the tender specification was taken for granted by most interviewees, it was cited as an important difference between contracting in Germany and Great Britain by the international providers we visited (for-profits c \& d). Management at for-profit d brought this issue up immediately when we asked at the beginning of the interview about how they entered the sector. The formal qualifications of workers,

depend on the position and the scheme. In Germany it is much stricter in the tender specifications which qualification staff have to have. I have learned that in Britain you are allowed to employ whoever you want to - the main thing is you find people jobs in the labour market. Here [in Germany] you need a social work background or a completed apprenticeship and certain years of professional experience (manager 1).

This did not stop downward pressure on wages (Gläser 2010), but it did matter for the work. Management lacked the discretion to replace qualified social workers with a diverse mixture of results-oriented individuals, because the tender specification did not permit it. As we saw above, qualified social workers tended to resist pressures to cream and park; in many cases they also disagreed with the work-first orientation of social policy.

The non-market institutions that explain the differences between the German nonprofit Bundesagentur contractor and other organisations subject to marketised funding are 
the arrangements governing worker skills well-known in comparative industrial relations; nevertheless, our picture does not correspond to the image of liberal Britain versus coordinated Germany (Hall and Soskice 2001). As recent literature on German industrial relations would expect (Doellgast 2012), persistent institutional effects led to within-country differences, with some providers - especially traditional nonprofits - embedded in these traditional institutional frameworks. At other providers, however, we observed employers outside of the institutions of collective bargaining, workplace participation, and skill formation; by all accounts this is ubiquitous among the small providers operating under placement vouchers who face a far more volatile market than their larger British counterparts. Our findings confirm Jaehrling's (2015) argument that contracting arrangements matter, since the funder required contractors to employ qualified social workers; such requirements were absent from British Work Programme contracting and German placement vouchers.

\section{Conclusion}

Above we examined the causes of creaming and parking in marketised employment services. Tight price-based competition was used by funders in both countries. We observed creaming and parking all of the Work Programme 'prime contractors' (for profits and a nonprofit) and the German placement vouchers (a for-profit firm). It was absent, however, from the German contractor (a large nonprofit), and Work Programme subcontractors tried with varying degrees of success to avoid it (municipalities and a nonprofit). Table 3 summarises the differences between the cases along the conditions and outcomes presented in table 1 . While these findings are not representative of all workplaces in these countries, they do suggest new ways to explain and interpret variation and change in government-funded services. 


\section{INSERT TABLE 3 ABOUT HERE}

Our first contribution is to provide a definition and operationalisation of marketisation that can be applied more generally to studies of government-funded services. The governance approach to marketisation focuses on principles and is non-specific regarding practices, while sociology of work and comparative employment relations approaches uses ad hoc and context-specific definitions. Our definition of marketization (building on Doellgast and Greer 2017), by contrast, specifies generic but concrete features of transactions - frequency, openness, standardisation, and the price mechanism - that could cause change in services and workplaces in diverse contexts. One contribution of this paper is to show qualitatively the workings of transactions along these dimensions.

Our second contribution is to identify two mechanisms through which marketization produces the kind of organizational change that might affect service quality, in this instance, creaming and parking. Our main theoretical insight here is that marketisation effects are not determined by the incentives set by funders (Anderson et al 1993, Le Grand 2003), but that different kinds of organisations will respond to incentives in different ways. We therefore assume that the mechanisms are different for commercial and non-commercial providers. Our first research question concerns commercial providers and draws on governance theory (Considine and Lewis 2003, Jantz et al 2016). We find that marketisation led to the rise of new forms of commercial provision characterised by tight management control and work-first services, and therefore prone to creaming and parking. Our second research question concerns pressures on non-commercial providers, drawing on the labour process tradition (Baines 2004, Cunningham et al 2013, Esbenshade et al 2016). We find that marketisation 
corroded existing non-commercial forms of provision characterised by strong professional autonomy and often resistant to creaming and parking.

Our third contribution concerns empirical differences between these commercial and non-commercial providers in Germany and Britain. Drawing on comparative employment relations (Doellgast 2012, Greer et al 2013, Jaehrling 2015), we explore the consequences of institutional differences on the effects of marketization in these providers. We find that commercial organizations in the two countries responded to broadly similar market conditions similarly, including engaging in creaming and parking. We also find in both countries differences between commercial and non-commercial organizations, and find nonprofits in both countries resisting pressures to become more like profit-making firms (albeit under severe financial pressure that calls into question sustainability). German nonprofits had the strongest resistance to marketization pressures, not because of any automatic nationalinstitutional effect (these institutions did not constrain providers operating under voucher schemes), but because the purchaser had structured the transaction in a way that shored up institutional supports for professional skills. The devaluation of professions by NPM tools (cites) is, we show, powerful but works in varying ways depending on institutional differneces and the exact workings of the transaction.

The lines of the policy debate over marketisation are between economists and policymakers who see great potential (Le Grand 2003, Freud 2007) and critical researchers who show that it does not in practice deliver (Davies 2008, Bredgaard and Larsen 2008). Our explanation points beyond this debate by pointing to organisational reasons why marketisation often does not deliver.

Our findings suggest that policymakers cannot solve service quality problems merely by adjusting incentives. What is needed may be both a change in the kind of contractors and a 
strengthening of the professional autonomy of staff. But cancelling contracts, rebuilding the non-profit sector, and reforming funding practices to support high-quality services could pose financial, political, and legal difficulties.

More straightforward may be what we observe in Germany: the regulation of contractors through the prescription of workplace standards in contracts. Our interviewees in German nonprofits could point to many problems that funding practices caused for them. The level of detail in which the work was prescribed created a huge administrative burden shouldered by front-line workers and sapped their capabilities to innovate. The standardization of services also made it easier for the funder to compare offers and extract low prices, contributing to problems both of low pay and job insecurity (which the funder refrained from regulating). Nevertheless, whichever providers carried out these schemes had to employ qualified social workers, whose occupational ethos frustrated tight management control and made creaming and parking a difficult prospect.

One limitation of our study is that the problems discussed above do not exist in every government-funded service subject to marketization, and there are many conditions under which creaming and parking might appear that we have not consider. There is less scope for creaming where the outcome is difficult to measure, as in many training courses or services for people very far from the labour market, or where the clientele is less diverse, as in a jobplacement schemes for lone parents, and there is consequently less scope for sorting. But creaming and parking exist in other kinds of marketised services with measurable outcomes, incentives to achieve them, and the sorting of service users, such as schools and health services. Future research could assess the conditions under which our two mechanisms appear, in employment services and beyond. 
A second limit concerns the effects of marketisation on service outcomes. We do not merely mean income, employment, and benefit payment, which in the aggregate are affected by marketisation and privatisation only in small and highly mediated ways (Krug and Stephan 2016) or the effects of payment by results on performance for disadvantaged jobseekers being 'parked'. The main outstanding question is: how does 'creaming' affect the kinds of jobs and employer strategies for recipients of mainstream job-seekers benefits for those deemed job-ready (Greer 2016)? Understanding the signalling function of front-line workers in marketized employment services would illuminate the role of welfare reform in structuring inequality in present-day societies. 


\section{References}

Anderson K Burkhauser R and Raymond J (1993) The effect of creaming on placement rates under the Job Training Partnership Act. Industrial \& Labour Relations Review, 46(4): 613624.

Bach S and Bordogna L (2011) Varieties of new public management or alternative models? The reform of public service employment relations in industrialized democracies. The International Journal of Human Resource Management 22(11): 2281-2294.

Baines D (2004) Pro-market, non-market: the dual nature of organisational change in social services delivery. Critical Social Policy 24(1): 5-29.

Bernhard S and Kruppe T (2010) Vermittlungsgutscheine für Arbeitslose: Oft ausgegeben und selten eingelöst. Nuremburg: IAB.

Bode I (2003) Flexible response in changing environments: The German third sector model in transition. Nonprofit and Voluntary Sector Quarterly, 32(2): 190-210.

Bredgaard T and Larsen F (2008) Quasi-markets in employment policy: Do they deliver on promises? Social Policy and Society 7: 341-352.

Brodkin E (2007) Bureaucracy Redux: Management Reformism and the Welfare State. Journal of Public Administration Research and Theory 17(1): 1-17.

Carter B Danford A Howcroft D Richardson H Smith A and Taylor P (2011) 'All they lack is a chain': lean and the new performance management in the British civil service. New Technology, Work and Employment, 26(2): 83-97.

Carter E and Whitworth A (2015) Creaming and parking in quasi-marketised welfare-to-work schemes: designed out of or designed in to the UK work programme?. Journal of social policy, 44(02): 277-296.

Clarke J and Newman J (1997) The Managerial State. London: Sage.

Crawford E and Parry F (2010). Professionalising the welfare to work industry: developing a framework for action. Centre for Economic and Social Inclusion.

Cunningham I (2008) A race to the bottom? Exploring variations in employment conditions in the voluntary sector. Public Administration 86(4): 1033-1053.

Cunningham I Hearne G and James P (2013) Voluntary organisations and marketisation: a dynamic of employment degradation. Industrial relations journal, 44(2), 171-188.

Davies S (2008) Contracting out employment services to the third and private sectors: a critique. Critical Social Policy 28(2): 136-164.

Department for Work and Pensions (2013) Minimum service delivery standards for Work Programme providers. 
https://www.gov.uk/government/uploads/system/uploads/attachment_data/file/401645/provid er-minimum-service-delivery.pdf (Accessed 19 October 2015).

De Koning J (1993) Measuring the placement effects of two wage-subsidy schemes for the long-term unemployed. Empirical Economics, 18(3): 447-468.

Divay S (2008) Professionals of policies for fighting unemployment in France: the construction and de-construction of professionalism. European Societies 10(4): 673-686.

Doellgast V (2012) Disintegrating Democracy at Work. Ithaca: ILR Press.

Eisenhardt M (1989) Building Theories from case study research. Academy of Management Review, 14(4): 532-550

Enggruber R and Mergner U (eds.) (2007) Lohndumping und neue

Beschäftigungsbedingungen in der sozialen Arbeit. Berlin: Frank und Timme.

Esbenshade J Vidal M Fascilla G and Ono M (2016) Customer-driven management models for choiceless clientele? Business process reengineering in a Californian welfare agency. Work Employment and Society. 30(1), 77-96.

Freud D (2007). Reducing dependency, increasing opportunity: options for the future of welfare to work. London: DWP.

Hegele D (2009) Der Vermittlungsgutschein: Entwicklung von 2002 bis 2008 und Fortführung des erfolgreichen Instruments der Arbeitsvermittlung. BWV Verlag.

Hermann C and Flecker J (2011) The liberalisation of public services: Company reactions and consequences for employment and working conditions. Economic and Industrial Democracy 32(3): 523-544.

Foster D and Hoggett P (1999) Change in the benefits agency: empowering the exhausted worker? Work, Employment and Society 13(1): 19-39.

Glaser B Strauss A (1967) The discovery of grounded theory: Strategies for qualitative research. New York: Aldine de Gruyter.

Gläser A (Ed.) (2010) Schwarzbuch Beschäftigung in der Weiterbildung. Gewerkschaft Erziehung und Wissenschaft, Hauptvorstand.

Greer I Schulten T and Böhlke N (2013) How does market making affect industrial relations? Evidence from eight German hospitals. British Journal of Industrial Relations 51(2): 215239.

Greer I (2016) Welfare reform, precarity and the re-commodification of labour. Work, Employment \& Society. 30(1): 162-173. 
Greer I and Doellgast V (2017) Marketization, inequality, and institutional change. Toward a new framework for comparative employment relations. Journal of Industrial Relations. 59(2): 192-208.

Greer I Breidahl K Larsen F and Knuth M (2017) The Marketization of Employment Services: The Dilemmas of Europe's Work-First Welfare State. Oxford University Press.

Grimshaw D and Miozzo M (2009) New human resource management practices in knowledge-intensive business services firms: the case of outsourcing with staff transfer. Human Relations 62(10): 1521-1550.

Hall, P. and Soskice, D. (eds.) (2001) Varieties of Capitalism. Oxford: Oxford University Press.

Hedström P and Swedberg R (1998) Social mechanisms: An analytical approach to social theory. Cambridge University Press.

Hipp L and Warner M (2008) Market forces for the unemployed? Training vouchers in Germany and the USA. Social Policy and Administration 42(1): 77-101.

Hoggett P (2006) Conflict, ambivalence, and the contested purpose of public organisations. Human Relations 59(2): 175-194.

Jaehrling K (2015) The state as a 'socially responsible customer'? Public procurement between market-making and market-embedding. European Journal of Industrial Relations 21(2): 149-164.

Krug G and Stephan G (2016) Private and Public Placement Services for Hard-to-Place Unemployed Results from a Randomized Field Experiment. ILR Review, 69(2): 471-500.

Le Grand J (2003) Motivation, Agency, and Public policy: of Knights and Knaves, Pawns and Queens. Oxford: Oxford University Press.

Marchington M, Grimshaw D, Rubery J and Willmott H (eds.) (2005) Fragmenting work. Oxford: Oxford UP.

National Audit Office (2014) The Work Programme. Report, 2 July.

Ragin C (2000) Fuzzy-set Social Science. Chicago: University of Chicago Press.

Ranald P (1999) Impacts on employees of the competitive tendering of employment services. In Tiecher J (ed) Public Sector Industrial Relations: Australian and International Perspectives. Melbourne: Monash University, 232-256.

Rees J Taylor R and Damm C (2013a) Does sector matter?-understanding the experiences of providers in the work programme. Birmingham: Third Sector Research Centre 
Rees J, Whitworth A, and Carter E (2013b) Support for all in the UK Work Programme?

Differential payments, same old problem. Social Policy and Administration 48(2): 221-239.

Rosenthal P and Peccei R (2006) The social construction of clients by service agents in reformed welfare administration. Human Relations, 59(12): 1633-1658.

Sachße C \& Tennstedt F (1980) Geschichte der Armenfiirsorge in Deutschland. Vom Spàtmittelalter bis zum Ersten Weltkrieg, Stuttgart.

Sako M (1992) Price, quality and trust: Inter-firm relations in Britain and Japan, Cambridge University Press.

Vidal M (2013) Low-autonomy work and bad jobs in postfordist capitalism. Human Relations, 66(4): 587-612.

Wagner I (2015) Rule Enactment in a Pan-European Labour Market: Transnational Posted Work in the German Construction Sector. British Journal of Industrial Relations, 53(4): 692710 .

Wiggan J (2015) Varieties of marketisation in the UK: examining divergence in activation markets between Great Britain and Northern Ireland 2008-2014. Policy Studies 36(2): 1-18.

Yin R (1994) Case study research: Design and methods. Beverly Hills: Sage. 
Table 1. Three propositions on marketisation and effects

\begin{tabular}{|c|c|c|}
\hline & Commercial model & Noncommercial social services \\
\hline Selection of clients & $\begin{array}{l}\text { Only employability } \\
\text { Job-ready clients identified and } \\
\text { served and neglect of more needy } \\
\text { clients (creaming and parking) }\end{array}$ & $\begin{array}{l}\text { Employability and opportunity } \\
\text { Job-ready clients identified and } \\
\text { served; more needy clients referred } \\
\text { to services }\end{array}$ \\
\hline $\begin{array}{l}\text { The transaction } \\
\text { (Le Grand 2003, Greer } \\
\text { and Doellgast 2017) }\end{array}$ & $\begin{array}{l}\text { Emerge under marketisation } \\
\text { Open competition } \\
\text { Clear prescription } \\
\text { Strong price mechanism } \\
\text { Frequently recurring transactions }\end{array}$ & $\begin{array}{l}\text { Emerge under non-market funding } \\
\text { Closed networks } \\
\text { Co-production of services } \\
\text { Price not decisive } \\
\text { Provision uninterrupted by } \\
\text { transactions }\end{array}$ \\
\hline
\end{tabular}

\begin{tabular}{ll}
\hline & \multicolumn{1}{c}{ Propositions } \\
\hline Governance & Market principles \\
(Considine and Lewis & Commercial providers, including \\
2013, Jantz et al 2016) & for-profit \\
& Accountability through quantitative \\
& measurement of results \\
& Narrowly defined work-first services
\end{tabular}
Nonmarket principles
Traditional nonprofits and municipal providers
Accountability through qualitative assessments
Services for broadly defined needs

P1: Marketisation encourages the rise of new forms of commercial provision...

\begin{tabular}{|c|c|c|}
\hline $\begin{array}{l}\text { The labour process } \\
\text { (Baines 2004, Vidal 2013) }\end{array}$ & $\begin{array}{l}\text { Tight management control } \\
\text { IT systems used to manage } \\
\text { performance } \\
\text { Deskilling } \\
\text { Speedup of work } \\
\text { Punitive firing }\end{array}$ & $\begin{array}{l}\text { Professional autonomy } \\
\text { IT systems used for reporting and } \\
\text { procedure } \\
\text { Formal qualifications valued } \\
\text { Slow processes } \\
\text { Layoffs at contract end }\end{array}$ \\
\hline \multicolumn{3}{|c|}{ P2: Marketization puts pressure on an established social service model... } \\
\hline $\begin{array}{l}\text { 3. National institutions } \\
\text { (Doellgast 2012, } \\
\text { Jaehrling 2015) }\end{array}$ & $\begin{array}{l}\text { Liberalization } \\
\text { Weak limits to management } \\
\text { discretion }\end{array}$ & $\begin{array}{l}\text { Strong non-market institutions } \\
\text { Management discretion limited by } \\
\text { skills frameworks or industrial } \\
\text { relations institutions, underpinned } \\
\text { by contracting rules }\end{array}$ \\
\hline
\end{tabular}

P3: These effects are weaker where strong non-market workplace institutions are in force... 
Table 2. Interviews and interviewees

Great-Britain Wave 1: 2006-2011 (51 interviews)

\begin{tabular}{lll}
\hline Code & Note & Interviewees \\
\hline Funder A & DWP & 2 managers \\
Funder B & $\begin{array}{l}\text { Regional Development } \\
\text { Agency }\end{array}$ & 2 managers \\
Funder C & Local authority & 3 managers \\
Funder D & $\begin{array}{l}\text { Job Centre Plus (JCP) } \\
\text { Learning and Skills }\end{array}$ & 1 manager \\
Funder E & $\begin{array}{l}\text { Council } \\
\text { Welsh Assembly }\end{array}$ & 1 manager \\
Funder F & Government & \\
\hline
\end{tabular}

Providers

Public sector $\mathrm{A} \quad \mathrm{JCP}$

Public sector B Local authority

Public sector C Local authority

Nonprofit A-D Charity

Nonprofit E Charity 7 front-line staff

Others

UK Treasury 2 managers

Politician A 1 member of parliament

Cabinet Office 1 manager

Umbrella A-C Infrastructure bodies for the voluntary

sector, 1 manager each

3 policy officers, 1 UnionLearn staff

Trade union A 3 staff, 1 lay official at UNISON

Trade union B 4 staff at AMICUS
Consultant 1 human resources consultant

Wave 2: 2011-14 (51 interviews)

\begin{tabular}{|c|c|c|}
\hline Code & Note & Interviewees \\
\hline Funder A & DWP & 2 managers \\
\hline \multicolumn{3}{|l|}{ Providers } \\
\hline Public sector G & $\begin{array}{l}\text { Local authority subcontractor on } \\
\text { Work Programme (WP) }\end{array}$ & $\begin{array}{l}2 \text { managers, } \\
4 \text { front-line staff }\end{array}$ \\
\hline Public sector $\mathrm{H}$ & Local authority subcontractor WP & 1 manager \\
\hline Nonprofits H \& I & Local charity subcontractor WP & 1 manager each \\
\hline Nonprofit J & Large charity subcontractor WP & 1 manager \\
\hline Nonprofit C & Charity not on WP & $\begin{array}{l}3 \text { managers, } \\
5 \text { front-line staff }\end{array}$ \\
\hline Nonprofit K & Large charity prime provider WP & $\begin{array}{l}3 \text { managers, } \\
7 \text { front-line staff }\end{array}$ \\
\hline For-Profit D & Multinational prime provider WP & $\begin{array}{l}3 \text { managers, } \\
4 \text { front-line staff }\end{array}$ \\
\hline For-Profits E-H & Multinational prime providers WP & I manager each \\
\hline \multicolumn{3}{|l|}{ Others } \\
\hline Politician B & \multicolumn{2}{|c|}{1 member of Parliament with researcher } \\
\hline Umbrella D & \multicolumn{2}{|c|}{$\begin{array}{l}\text { Spokesperson for the Employment Related Services } \\
\text { Association }\end{array}$} \\
\hline Trade union $\mathrm{A}$ & \multicolumn{2}{|c|}{$\begin{array}{l}\text { Public and Commercial Services Union. } 4 \text { staff, } 3 \text { lay } \\
\text { officers }\end{array}$} \\
\hline Consultancy & \multicolumn{2}{|l|}{1 manager } \\
\hline
\end{tabular}

Wave 2: 2011-14 (20 interviews)

\begin{tabular}{|c|c|c|c|c|c|}
\hline Funder A & $\begin{array}{l}\text { Local Jobcenter / } \\
\text { municipality }\end{array}$ & 2 managers & Funder A & Local Jobcenter & 1 manager \\
\hline Providers & & & Funder B & $\begin{array}{l}\text { Regionales Einkaufszentrum } \\
\text { (REZ), BA }\end{array}$ & 2 managers \\
\hline Public sector A & $\begin{array}{l}\text { Bundesagentur für } \\
\text { Arbeit (BA) }\end{array}$ & 2 works councilors & Providers & & \\
\hline Public sector B & Local Jobcenter & $\begin{array}{l}1 \text { manager } \\
3 \text { works councilors }\end{array}$ & Public sector $\mathrm{C}$ & Jobcenter & 1 manager \\
\hline Nonprofits A, B, C, G & Association & 2 managers each & Nonprofit B & Large charity BA contractor & $\begin{array}{l}2 \text { managers, } \\
4 \text { front-line staff }\end{array}$ \\
\hline Nonprofit D & Association & 2 works councilors & For-profit B & $\begin{array}{l}\text { Small firm operating under } \\
\text { placement vouchers }\end{array}$ & $\begin{array}{l}2 \text { managers, } 5 \\
\text { front-line workers }\end{array}$ \\
\hline Nonprofit E, F & Association & 1 manager each & For-profits C \& D & Multinational firms & 1 manager each \\
\hline For-profits A \& B & Small firms & 1 manager each & Nonprofits $\mathrm{C} \& \mathrm{H}$ & Small charities BA contractors & 1 manager each \\
\hline $\begin{array}{l}\text { Others } \\
\text { Parliament }\end{array}$ & $1 \mathrm{SPD}$ researcher & & Other & \multirow{3}{*}{\multicolumn{2}{|c|}{$\begin{array}{l}1 \text { manager at Deutscher Paritätischer } \\
\text { Wohlfahrtsverband }\end{array}$}} \\
\hline Trade union $\mathrm{A}$ & 2 IG Metall staff & & Umbrella A & & \\
\hline Trade union B & 3 ver.di staff & & & & \\
\hline
\end{tabular}


Table 3. Summary of the cases

\begin{tabular}{|c|c|c|c|c|}
\hline \multirow{2}{*}{$\begin{array}{l}\text { Organisational model } \\
\text { Market segment }\end{array}$} & \multicolumn{2}{|c|}{ Commercial } & \multicolumn{2}{|c|}{ Non-Commercial } \\
\hline & $\begin{array}{l}\text { British WP } \\
\text { Primes }\end{array}$ & $\begin{array}{c}\text { German Job } \\
\text { Placement Vouchers }\end{array}$ & $\begin{array}{c}\text { British WP } \\
\text { Subcontractors }\end{array}$ & $\begin{array}{l}\text { German BA } \\
\text { Contractors }\end{array}$ \\
\hline Organisations & $\begin{array}{c}\text { Nonprofit and } \\
\text { for-profits }\end{array}$ & For-profit & $\begin{array}{l}\text { Small nonprofits } \\
\text { and municipalities }\end{array}$ & Large nonprofit \\
\hline \multicolumn{5}{|l|}{ Client selection } \\
\hline Employability & $\mathrm{H}$ & $\mathrm{H}$ & $\mathrm{H}$ & $\mathrm{H}$ \\
\hline Opportunity & L & $\mathrm{L}$ & $H / L$ & $\mathrm{H}$ \\
\hline \multicolumn{5}{|c|}{ Governance principles of funder } \\
\hline $\begin{array}{l}\text { Commercial orientation of } \\
\text { providers }\end{array}$ & $\mathrm{H}$ & $\mathrm{H}$ & $\mathrm{L}$ & $H / L$ \\
\hline Work-first approach & $\mathrm{H}$ & $\mathrm{H}$ & $H / L$ & $H / L$ \\
\hline $\begin{array}{l}\text { Quantitative results } \\
\text { orientation }\end{array}$ & $\mathrm{H}$ & $\mathrm{H}$ & $\mathrm{H}$ & $\mathrm{H}$ \\
\hline \multicolumn{5}{|l|}{ Labour process at provider } \\
\hline Individual targets used & $H / L$ & $\mathrm{H}$ & $\mathrm{L}$ & $\mathrm{L}$ \\
\hline Deskilling & $\mathrm{H}$ & $\mathrm{H}$ & $\mathrm{H}$ & L \\
\hline Speed of processes & $\mathrm{H}$ & $\mathrm{H}$ & $H / L$ & $\mathrm{~L}$ \\
\hline Punitive firing & $H / L$ & $\mathrm{H}$ & $\mathrm{L}$ & L \\
\hline \multicolumn{5}{|l|}{ National institutions } \\
\hline \multicolumn{5}{|l|}{ Importance of: } \\
\hline $\begin{array}{l}\text { Worker representation and } \\
\text { collective bargaining }\end{array}$ & $H / L$ & $\mathrm{~L}$ & $H / L$ & $\mathrm{H}$ \\
\hline Formal qualifications & $\mathrm{L}$ & $\mathrm{L}$ & $\mathrm{L}$ & $\mathrm{H}$ \\
\hline
\end{tabular}

$L=$ low,$H=$ high,$H / L=$ mixed. 


\section{Figure 1. Dynamic model}

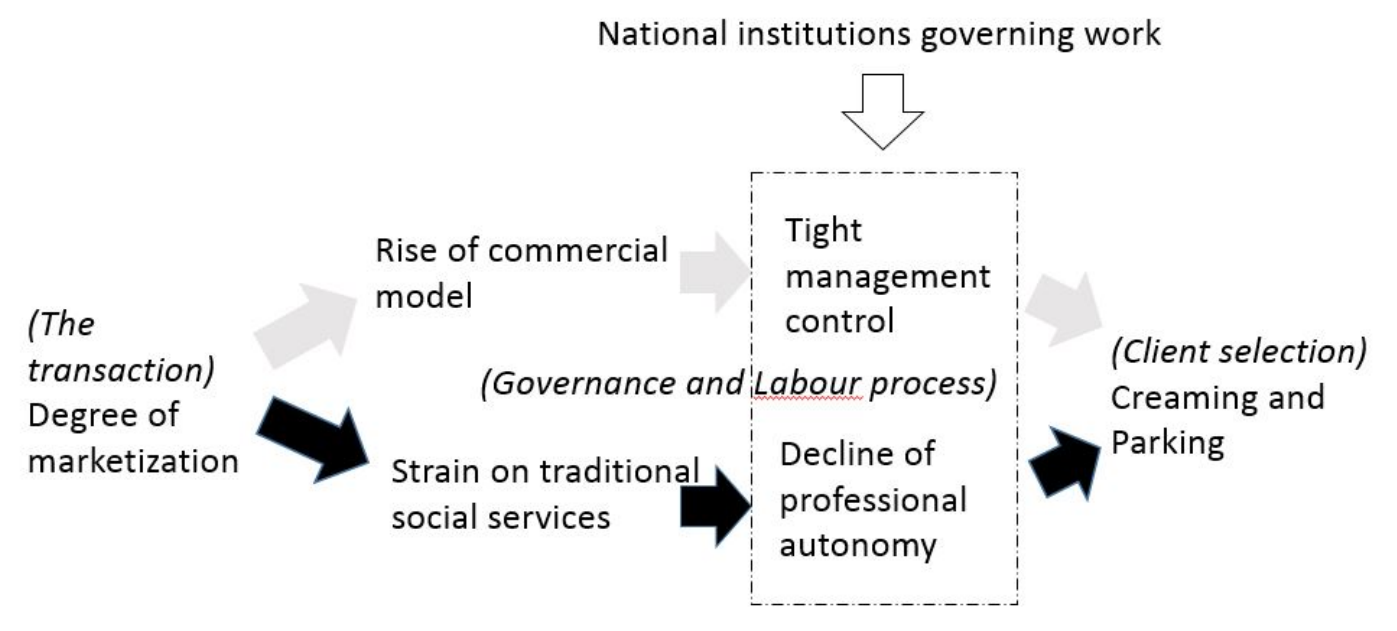

\section{Figure 2. The Work Programme}

DWP

Selects and pays prime provider, refers clients

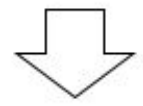

Prime provider

Selects and manages

subcontractor, designs work, refers clients, may provide

general service

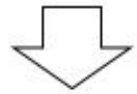

Subcontractor

Provides specialized service 


\section{Figure 3. Placement vouchers}

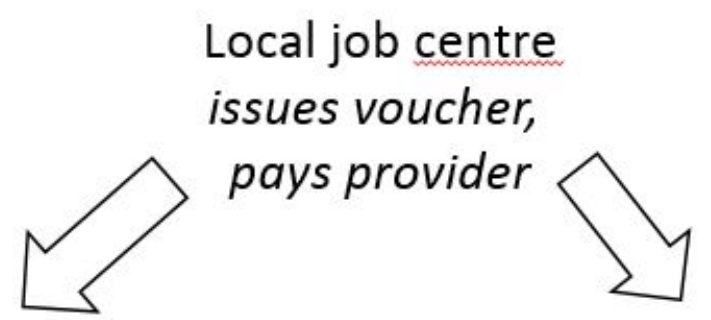

Private firm

Finds clients,

delivers service,

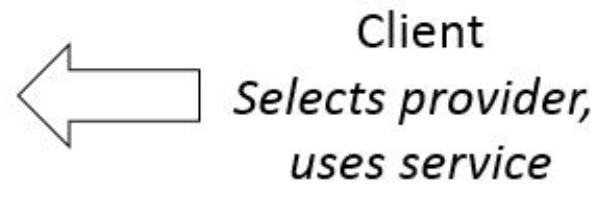

redeems voucher

\section{Figure 4. Bundesagentur für Arbeit (BA) contracting (post-marketization)}

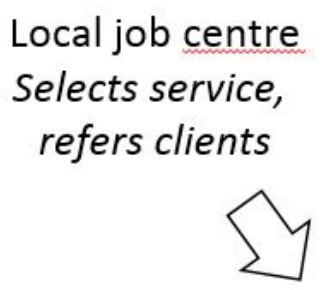

Provider

Bids for contract, delivers service, claims funding
REZ

may design service, selects provider, manages contract

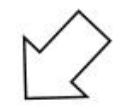

